\title{
Geographical patterns of woody plants' functional traits in Burkina Faso
}

\author{
Marco Schmidt, Salifou Traoré, Amadé Ouédraogo, Elisée Mbayngone, Oumarou Ouédraogo, Alexander Zizka, \\ Ivana Kirchmair, Elice Kaboré, Elycée Tindano, Adjima Thiombiano, Karen Hahn \& Georg Zizka
}

\begin{abstract}
SCHMIDT, M., S. TRAORÉ, A. OUÉDRAOGO, E. MBAYNGONE, O. OUÉDRAOGO, A. ZIZKA, I. KIRCHMAIR, E. KABORÉ, E. TINDANO, A. THIOMBIANO, K. HAHN \& G. ZIZKA (2013). Geographical patterns of woody plants' functional traits in Burkina Faso. Candollea 68: 197-207. In English, English and French abstracts.

The West African vegetation zones from the Sahara desert to the Guinean rainforests are shaped by a steep latitudinal precipitation gradient. Their taxonomical and functional composition changes considerably along this gradient. Based on comprehensive distribution data from herbariun collections and relevés this paper presents modelled distributions of the 129 most frequent woody taxa of Burkina Faso with climatic, topographic and remote sensing parameters at a $1 \mathrm{~km}$ resolution as predictor variables. Subsequently we analysed this set of modelled distributions according to their functional composition. The resulting maps show clear geographical patterns for several key traits such as spinescence, plant size, flowering phenology and fruit type. The interactions between environmental factors and plant functional traits are discussed.
\end{abstract}

\section{Key-words}

Burkina Faso - Ecological gradients - Plant functional traits - Savanna - Species distribution models - Trees

\begin{abstract}
Résumé
SCHMIDT, M., S. TRAORÉ, A. OUÉDRAOGO, E. MBAYNGONE, O. OUÉDRAOGO, A. ZIZKA, I. KIRCHMAIR, E. KABORÉ, E. TINDANO A. THIOMBIANO, K. HAHN \& G. ZIZKA (2013). Distribution géographique des plantes ligneuses selon leurs traits fonctionnels au Burkina-Faso. Candollea 68: 197-207. En anglais, résumés anglais et français.
\end{abstract}

Les zones de végétation de l'Afrique de l'Ouest du désert du Sahara aux forêts humides guinéennes sont modelées par un gradient latitudinal de précipitation. Leurs compositions taxonomiques et en traits fonctionnels varient considérablement le long de ce gradient. Sur la base de données issues de collections d'herbier et de relevés, cet article présente la distribution modélisée de 129 taxons ligneux les plus fréquents du Burkina Faso sur la base de prédicteurs climatiques, topographiques et d'images satellitaires à $1 \mathrm{~km}$ de résolution. Les distributions modélisées ont été aussi analysées avec les traits fonctionnels propres à chaque taxon. Les cartes de distribution qui en résultent montrent clairement des tendances géographiques pour plusieurs traits fonctionnels clés comme la spinescence, la taille des plantes, la phénologie de la floraison et le type de fruit. Les interactions entre les facteurs environnementaux et ces traits fonctionnels sont discutés.

\footnotetext{
Addresses of the authors: MS, GZ: Senckenberg Research Institute, Department of Botany and molecular Evolution and Biodiversity and Climate Research Centre (BiK-F), Senckenberganlage 25, 60325 Frankfurt am Main; Germany and Goethe University, Institute for Ecology, Evolution and Diversity, Max-von-Laue-Str. 13, 60438 Frankfurt am Main, Germany. Email: marco.schmidt@ senckenberg.de

AZ: Senckenberg Research Institute, Department of Botany and molecular Evolution, Senckenberganlage 25, 60325 Frankfurt am Main, Germany.

KH, IK: Biodiversity and Climate Research Centre (BiK-F), Senckenberganlage 25, 60325 Frankfurt am Main; Germany and Goethe University, Institute for Ecology, Evolution and Diversity, Max-von-Laue-Str. 13, 60438 Frankfurt am Main, Germany.
}

ST, AO, OO, ET, AT: University of Ouagadougou, UFR/SVT, Laboratoire de Biologie et Ecologie Végétales, 03 BP 7021 Ouagadougou 03, Burkina Faso.

EM: University of N'Djaména, Faculty of Exact and Applied Sciences, BP 1027, N'Djaména, Chad. 


\section{Introduction}

West Africa is climatically characterized by a steep precipitation gradient that is reflected in the vegetation zones from the Sahara desert to the Guinean rainforests. These zones run in parallel bands throughout the subcontinent and the general latitudinal pattern is only in few places overlaid by topography, e.g. in the Nimba mountains, the Jos Plateau, Mt Cameroon and the Bamenda Highlands.

The abundance and diversity of woody plants increases from the North to the South. While the savanna-forest boundary is usually characterized by abrupt changes and mosaics in the areas of transition (HENNENBERG \& al., 2005), the transition between different savanna types in the Sudanian and Sahelian zones is rather gentle. The natural vegetation throughout the region is mainly confined to protected areas, most land has been converted into cultural landscapes, with different use forms prevailing along the climatic gradient: plantations, parklands or pastures (HAHN \& al., 2010).

In our study we focus on Burkina Faso, a landlocked country in the center of West Africa that can in many ways be seen as a model case for the whole sahelo-sudanian savanna region. Burkina Faso is rather flat with an altitudinal range of only $600 \mathrm{~m}$ between the lowest areas in the floodplains of the Pendjari River at the South-eastern border with Benin and the highest peak at Mt. Ténakourou in the Southwest. Its vegetation is characterized by Sahelian and Sudanian savannas and woodlands with acacias dominating the woody flora in the North (WitTig \& al., 2004) and Combretaceae replacing them continually towards the South (Thiombiano \& al., 2006). Some Guinean elements are present in the gallery forests (SAMBARÉ $\&$ al., 2011) and the few remaining island forests in the Southwest (GNOUMOU \& al., 2011).

Woody plants in Burkina Faso are still the main source of energy, medicine and other non-timber forest products as well as various ecosystem services, including soil preservation and water retention, and the local population is highly dependent on them (TAÏTA, 2003; LYKKE \& al., 2004; OUOBA \& al., 2006; BELEM \& al., 2007). As primary producers and structural habitat components they are, together with the grasses (SCHMIDT \& al., 2011), the base of the region's ecosystems.

Since woody plants are highly important both ecologically and economically, the aim of this study is to investigate in detail the geographical patterns of the most frequent woody species of Burkina Faso. In particular, we want to answer the following questions: What are the distribution patterns of functional groups of woody plants in Burkina Faso? Which environmental factors are contributing most to these patterns?

\section{Material and methods}

Plant distribution data is very unevenly distributed throughout our study area. Most data is confined to sampling hotspots, regional studies often had also a focus on particular habitats or species groups. Therefore we modeled species distributions with Maxent to extrapolate the distributional information to the whole area of Burkina Faso.

\section{Botanical distribution data}

Botanical distribution data has been assembled from collections and observation data of the University of Ouagadougou and the Research Institute Senckenberg. We compiled data from the collection databases of the herbaria of both institutes (OUA, FR) and their vegetation data stored in the West African Vegetation Database (JANSSEN \& al., 2011; SCHMIDT \& al., 2012; West AfricAN VegetATION, 2013) and comprising the original studies of HAHN (1996), Kéré (1996), KÜPPERS (1996), BÖHM (1998), DENSCHLAG (1998), ATAHOLO (2001), Sieglstetter (2002), Krohmer (2004), Thiombiano (2005), OuÉdraogo (2006), SCHMidt (2006), Kirchmair (2009), MbaYngone (2008), OuÉDraogo (2009) and ZwARG (2008). To reduce edge effects we included also data from neighbouring countries, e.g. from the BIOTA observatory in Comoé NP in Ivory Coast (KouliBaly \& al., 2006). Herbarium and field determinations have been done with ARBONNIER (2002), HUtCHINSON \& DALZIEL (1954-1972), BERHAUT (19711988), AKoÈGnINou \& al. (2006) and the West African Plants Database (BRunKen \& al., 2008; West African Vegetation, 2013). The nomenclature has been adjusted to names accepted in the African Plants Database (KLOPPER \& al., 2007) and doubles have been excluded. To obtain reliable models and to focus on species that determine the patterns of woody vegetation within the country, we excluded all species with less than 50 distribution records. The remaining set of distribution records comprised 36397 records of 129 species, representing about $15 \%$ of the woody species of Burkina Faso (THIOMBIANo \& al., 2010; THIOMBIANO \& al., 2012).

\section{Plant functional traits data}

Data on plant functional traits have been taken from literature (BERHAUT, 1971-1988; ARBONNIER, 2002; LOUPPE $\&$ al., 2008), completed with own observations from field work and herbarium material and assigned to the species (Table 1). The choice of traits has been restricted by a limited availability of trait data for West African woody plants, so we focussed on well documented traits. 
Table 1. - List of the 129 most frequent woody species of Burkina Faso and their respective trait values.

\begin{tabular}{|c|c|c|c|c|c|c|c|c|}
\hline & Size $\max [\mathrm{m}]$ & $\begin{array}{l}\text { Spinescence } \\
{[\mathrm{Y} / \mathrm{N}]}\end{array}$ & Latex $[\mathrm{Y} / \mathrm{N}]$ & $\begin{array}{l}\text { Compound } \\
\text { leaves }[\mathrm{Y} / \mathrm{N}]\end{array}$ & $\begin{array}{l}\text { Dry fruits } \\
{[\mathrm{Y} / \mathrm{N}]}\end{array}$ & $\begin{array}{l}\text { Dehiscent } \\
\text { fruits }[\mathrm{Y} / \mathrm{N}]\end{array}$ & $\begin{array}{l}\text { Mean fruit } \\
\text { length }[\mathrm{mm}]\end{array}$ & $\begin{array}{l}\text { Flowering in } \\
\text { rainy } \\
\text { season }[\mathrm{Y} / \mathrm{N}]\end{array}$ \\
\hline Acacia ataxacantha DC. & 5 & $Y$ & $\mathrm{~N}$ & 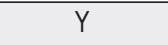 & $Y$ & $Y$ & 85 & $Y$ \\
\hline Acacia erythrocalyx Brenan & 10 & Y & $\mathrm{N}$ & Y & Y & Y & 125 & Y \\
\hline Acacia gourmaensis A. Chev. & 4 & Y & $\mathrm{N}$ & Y & Y & Y & 50 & Y \\
\hline Acacia macrostachya DC. & 8 & Y & $\mathrm{N}$ & Y & Y & Y & 95 & $\mathrm{~N}$ \\
\hline Acacia nilotica (L.) Delile & 20 & Y & $\mathrm{N}$ & Y & Y & Y & 125 & Y \\
\hline Acacia polyacantha Willd. & 25 & Y & $\mathrm{N}$ & Y & Y & Y & 95 & Y \\
\hline Acacia senegal (L.) Willd. & 6 & Y & $\mathrm{N}$ & Y & Y & Y & 90 & Y \\
\hline Acacia seyal Delile & 10 & Y & $\mathrm{N}$ & Y & Y & Y & 135 & $\mathrm{~N}$ \\
\hline Afzelia africana Pers. & 30 & $\mathrm{~N}$ & $\mathrm{~N}$ & Y & Y & Y & 140 & Y \\
\hline Albizia chevalieri Harms & 12 & $\mathrm{~N}$ & $\mathrm{~N}$ & Y & Y & Y & 87.5 & $\mathrm{~N}$ \\
\hline Allophylus africanus P. Beauv. & 8 & $\mathrm{~N}$ & $\mathrm{~N}$ & Y & $\mathrm{N}$ & $\mathrm{N}$ & 7 & Y \\
\hline Annona senegalensis Pers. & 4 & $\mathrm{~N}$ & $\mathrm{~N}$ & $\mathrm{~N}$ & $\mathrm{~N}$ & $\mathrm{~N}$ & 40 & Y \\
\hline Anogeissus leiocarpa (DC.) Guill. \& Perr. & 25 & $\mathrm{~N}$ & $\mathrm{~N}$ & $\mathrm{~N}$ & Y & $\mathrm{N}$ & 5.5 & $\mathrm{~N}$ \\
\hline Baissea multiflora A. DC. & - & $\mathrm{N}$ & Y & $\mathrm{N}$ & Y & Y & 450 & $\mathrm{~N}$ \\
\hline Balanites aegyptiaca (L.) Delile & 9 & Y & $\mathrm{N}$ & Y & $\mathrm{N}$ & $\mathrm{N}$ & 50 & $\mathrm{~N}$ \\
\hline Bauhinia rufescens Lam. & 5 & Y & $\mathrm{N}$ & $\mathrm{N}$ & Y & $\mathrm{N}$ & 75 & Y \\
\hline $\begin{array}{l}\text { Bobgunnia madagascariensis } \\
\text { (Desv.) J. H. Kirkbr. \& Wiersema }\end{array}$ & 6 & $\mathrm{~N}$ & $\mathrm{~N}$ & Y & Y & Y & 300 & $\mathrm{~N}$ \\
\hline Bombax costatum Pellegr. \& Vuill. & 25 & Y & $\mathrm{N}$ & Y & Y & Y & 110 & $\mathrm{~N}$ \\
\hline Calotropis procera (Aiton) R. Br. & 5 & $\mathrm{~N}$ & Y & $\mathrm{N}$ & Y & Y & 75 & Y \\
\hline Cassia sieberiana DC. & 10 & $\mathrm{~N}$ & $\mathrm{~N}$ & Y & Y & $\mathrm{N}$ & 500 & $\mathrm{~N}$ \\
\hline Cassia singueana Delile & 10 & $\mathrm{~N}$ & $\mathrm{~N}$ & Y & Y & $\mathrm{N}$ & 125 & Y \\
\hline Cissus populnea Guill. \& Perr. & 10 & $\mathrm{~N}$ & $\mathrm{~N}$ & $\mathrm{~N}$ & $\mathrm{~N}$ & $\mathrm{~N}$ & 17.5 & Y \\
\hline Combretum aculeatum Vent. & 3 & $\mathrm{~N}$ & $\mathrm{~N}$ & $\mathrm{~N}$ & Y & $\mathrm{N}$ & 19 & Y \\
\hline Combretum adenogonium A. Rich. & 12 & $\mathrm{~N}$ & $\mathrm{~N}$ & $\mathrm{~N}$ & Y & $\mathrm{N}$ & 30 & Y \\
\hline Combretum collinum Fresen. & 8 & $\mathrm{~N}$ & $\mathrm{~N}$ & $\mathrm{~N}$ & Y & $\mathrm{N}$ & 32.5 & $\mathrm{~N}$ \\
\hline Combretum glutinosum DC. & 10 & $\mathrm{~N}$ & $\mathrm{~N}$ & $\mathrm{~N}$ & Y & $\mathrm{N}$ & 32.5 & $\mathrm{~N}$ \\
\hline Combretum micranthum G. Don & 4 & $\mathrm{~N}$ & $\mathrm{~N}$ & $\mathrm{~N}$ & Y & $\mathrm{N}$ & 13.5 & $\mathrm{~N}$ \\
\hline Combretum molle G. Don & 10 & $\mathrm{~N}$ & $\mathrm{~N}$ & $\mathrm{~N}$ & Y & $\mathrm{N}$ & 20 & $\mathrm{~N}$ \\
\hline Combretum nigricans Guill. \& Perr. & 8 & $\mathrm{~N}$ & $\mathrm{~N}$ & $\mathrm{~N}$ & Y & $\mathrm{N}$ & 22.5 & $\mathrm{~N}$ \\
\hline Combretum paniculatum Vent. & 3 & Y & $\mathrm{N}$ & $\mathrm{N}$ & Y & $\mathrm{N}$ & 25 & $\mathrm{~N}$ \\
\hline Commiphora africana (A. Rich.) Engl. & 6 & Y & $\mathrm{N}$ & Y & $\mathrm{N}$ & $\mathrm{N}$ & 7.5 & $\mathrm{~N}$ \\
\hline Crossopteryx febrifuga (G. Don) Benth. & 6 & $\mathrm{~N}$ & $\mathrm{~N}$ & $\mathrm{~N}$ & Y & Y & 10 & $\mathrm{~N}$ \\
\hline Dalbergia melanoxylon Guill. \& Perr. & 7 & Y & $\mathrm{N}$ & Y & Y & $\mathrm{N}$ & 45 & $\mathrm{~N}$ \\
\hline Daniellia oliveri (Rolfe) Hutch. \& Dalziel & 20 & $\mathrm{~N}$ & $\mathrm{~N}$ & Y & Y & Y & 75 & $\mathrm{~N}$ \\
\hline
\end{tabular}


Table 1. - Cont.

\begin{tabular}{|c|c|c|c|c|c|c|c|c|}
\hline & Size $\max [\mathrm{m}]$ & $\begin{array}{c}\text { Spinescence } \\
{[Y / N]}\end{array}$ & Latex $[\mathrm{Y} / \mathrm{N}]$ & $\begin{array}{l}\text { Compound } \\
\text { leaves }[\mathrm{Y} / \mathrm{N}]\end{array}$ & $\begin{array}{l}\text { Dry fruits } \\
{[\mathrm{Y} / \mathrm{N}]}\end{array}$ & $\begin{array}{c}\text { Dehiscent } \\
\text { fruits }[\mathrm{Y} / \mathrm{N}]\end{array}$ & $\begin{array}{l}\text { Mean fruit } \\
\text { length }[\mathrm{mm}]\end{array}$ & $\begin{array}{c}\text { Flowering in } \\
\text { rainy } \\
\text { season }[\mathrm{Y} / \mathrm{N}]\end{array}$ \\
\hline Detarium microcarpum Guill. \& Perr. & 10 & $\mathrm{~N}$ & $\mathrm{~N}$ & $Y$ & $\mathrm{~N}$ & $\mathrm{~N}$ & 37.5 & $Y$ \\
\hline Diospyros mespiliformis A. DC. & 15 & $\mathrm{~N}$ & $\mathrm{~N}$ & $\mathrm{~N}$ & $\mathrm{~N}$ & $\mathrm{~N}$ & 22.5 & $\mathrm{~N}$ \\
\hline Dombeya quinqueseta (Delile) Exell & 5 & $\mathrm{~N}$ & $\mathrm{~N}$ & $\mathrm{~N}$ & Y & Y & 5.5 & $\mathrm{~N}$ \\
\hline Feretia apodanthera Delile & 4 & $\mathrm{~N}$ & $\mathrm{~N}$ & $\mathrm{~N}$ & $\mathrm{~N}$ & $\mathrm{~N}$ & 6.5 & $\mathrm{~N}$ \\
\hline Ficus cordata Thunb. & 5 & $\mathrm{~N}$ & Y & $\mathrm{N}$ & $\mathrm{N}$ & $\mathrm{N}$ & 6.5 & Y \\
\hline Ficus sur Forssk. & 8 & $\mathrm{~N}$ & Y & $\mathrm{N}$ & $\mathrm{N}$ & $\mathrm{N}$ & 32.5 & Y \\
\hline Ficus sycomorus L. & 15 & $\mathrm{~N}$ & Y & $\mathrm{N}$ & $\mathrm{N}$ & $\mathrm{N}$ & 32.5 & Y \\
\hline Flueggea virosa (Willd.) Voigt & 3 & $\mathrm{~N}$ & $\mathrm{~N}$ & $\mathrm{~N}$ & $\mathrm{~N}$ & $\mathrm{~N}$ & 6 & $\mathrm{~N}$ \\
\hline Gardenia ternifolia Schumach. \& Thonn. & 6 & $\mathrm{~N}$ & $\mathrm{~N}$ & $\mathrm{~N}$ & $\mathrm{~N}$ & $\mathrm{~N}$ & 70 & $\mathrm{~N}$ \\
\hline Grewia bicolor Juss. & 8 & $\mathrm{~N}$ & $\mathrm{~N}$ & $\mathrm{~N}$ & $\mathrm{~N}$ & $\mathrm{~N}$ & 5 & Y \\
\hline Grewia flavescens Juss. & 8 & $\mathrm{~N}$ & $\mathrm{~N}$ & $\mathrm{~N}$ & $\mathrm{~N}$ & $\mathrm{~N}$ & 10 & Y \\
\hline Grewia lasiodiscus K. Schum. & 6 & $\mathrm{~N}$ & $\mathrm{~N}$ & $\mathrm{~N}$ & $\mathrm{~N}$ & $\mathrm{~N}$ & 11 & Y \\
\hline Grewia mollis Juss. & 5 & $\mathrm{~N}$ & $\mathrm{~N}$ & $\mathrm{~N}$ & $\mathrm{~N}$ & $\mathrm{~N}$ & 9 & $\mathrm{~N}$ \\
\hline Grewia tenax (Forssk.) Fiori & 3 & $\mathrm{~N}$ & $\mathrm{~N}$ & $\mathrm{~N}$ & $\mathrm{~N}$ & $\mathrm{~N}$ & 10 & Y \\
\hline Grewia villosa Willd. & 3 & $\mathrm{~N}$ & $\mathrm{~N}$ & $\mathrm{~N}$ & $\mathrm{~N}$ & $\mathrm{~N}$ & 10 & Y \\
\hline Guiera senegalensis J. F. Gmel. & 2 & $\mathrm{~N}$ & $\mathrm{~N}$ & $\mathrm{~N}$ & Y & $\mathrm{N}$ & 37.5 & Y \\
\hline Gymnosporia senegalensis (Lam.) Loes. & 6 & Y & $\mathrm{N}$ & $\mathrm{N}$ & Y & Y & 5.5 & $\mathrm{~N}$ \\
\hline Hexalobus monopetalus (A. Rich.) Engl. \& Diels & 8 & $\mathrm{~N}$ & $\mathrm{~N}$ & $\mathrm{~N}$ & $\mathrm{~N}$ & $\mathrm{~N}$ & 50 & Y \\
\hline Holarrhena floribunda (G. Don) T. Durand \& Schinz & $\mathrm{nz} \quad 15$ & $\mathrm{~N}$ & Y & $\mathrm{N}$ & Y & Y & 33 & Y \\
\hline Lannea microcarpa Engl. \& K. Krause & 15 & $\mathrm{~N}$ & $\mathrm{~N}$ & Y & $\mathrm{N}$ & $\mathrm{N}$ & 14 & $\mathrm{~N}$ \\
\hline Lannea velutina A. Rich. & 8 & $\mathrm{~N}$ & $\mathrm{~N}$ & Y & $\mathrm{N}$ & $\mathrm{N}$ & 10 & $\mathrm{~N}$ \\
\hline Lophira lanceolata Keay & 15 & $\mathrm{~N}$ & $\mathrm{~N}$ & $\mathrm{~N}$ & Y & $\mathrm{N}$ & 19 & $\mathrm{~N}$ \\
\hline Maerva angolensis DC. & 10 & $\mathrm{~N}$ & $\mathrm{~N}$ & $\mathrm{~N}$ & $\mathrm{~N}$ & $\mathrm{~N}$ & 250 & $\mathrm{~N}$ \\
\hline Maerua crassifolia Forssk. & 10 & $\mathrm{~N}$ & $\mathrm{~N}$ & $\mathrm{~N}$ & $\mathrm{~N}$ & $\mathrm{~N}$ & 35 & Y \\
\hline Manilkara obovata (Sabine \& G. Don) J. H. Hemsl. & sl. 10 & $\mathrm{~N}$ & $\mathrm{~N}$ & $\mathrm{~N}$ & $\mathrm{~N}$ & $\mathrm{~N}$ & 16 & $\mathrm{~N}$ \\
\hline Maranthes polyandra (Benth.) Prance & 8 & $\mathrm{~N}$ & $\mathrm{~N}$ & $\mathrm{~N}$ & $\mathrm{~N}$ & $\mathrm{~N}$ & 22.5 & Y \\
\hline Mitragyna inermis (Willd.) Kuntze & 10 & $\mathrm{~N}$ & $\mathrm{~N}$ & $\mathrm{~N}$ & Y & Y & 5 & Y \\
\hline Ochna schweinfurthiana F. Hoffm. & 8 & $\mathrm{~N}$ & $\mathrm{~N}$ & $\mathrm{~N}$ & $\mathrm{~N}$ & $\mathrm{~N}$ & 4.5 & $\mathrm{~N}$ \\
\hline Opilia amentacea Roxb. & 10 & $\mathrm{~N}$ & $\mathrm{~N}$ & $\mathrm{~N}$ & $\mathrm{~N}$ & $\mathrm{~N}$ & 22.5 & $\mathrm{~N}$ \\
\hline Ozoroa obovata (Oliv.) R. Fern. \& A. Fern. & 6 & $\mathrm{~N}$ & $\mathrm{~N}$ & $\mathrm{~N}$ & $\mathrm{~N}$ & $\mathrm{~N}$ & 12 & Y \\
\hline Parinari curatellifolia Benth. & 7 & $\mathrm{~N}$ & $\mathrm{~N}$ & $\mathrm{~N}$ & $\mathrm{~N}$ & $\mathrm{~N}$ & 27.5 & $\mathrm{~N}$ \\
\hline Parkia biglobosa (Jacq.) G.Don & 15 & $\mathrm{~N}$ & $\mathrm{~N}$ & Y & Y & Y & 250 & $\mathrm{~N}$ \\
\hline Paullinia pinnata L. & 8 & $\mathrm{~N}$ & $\mathrm{~N}$ & Y & Y & Y & 25 & Y \\
\hline Pavetta crassipes K. Schum. & 6 & $\mathrm{~N}$ & $\mathrm{~N}$ & $\mathrm{~N}$ & $\mathrm{~N}$ & $\mathrm{~N}$ & 8 & Y \\
\hline Pericopsis laxiflora (Benth.) Meeuwen & 7 & $\mathrm{~N}$ & $\mathrm{~N}$ & Y & Y & $\mathrm{N}$ & 100 & Y \\
\hline
\end{tabular}


Table 1. - Cont.

\begin{tabular}{|c|c|c|c|c|c|c|c|c|}
\hline & Size $\max [\mathrm{m}]$ & $\begin{array}{l}\text { Spinescence } \\
{[\mathrm{Y} / \mathrm{N}]}\end{array}$ & Latex $[\mathrm{Y} / \mathrm{N}]$ & $\begin{array}{l}\text { Compound } \\
\text { leaves }[\mathrm{Y} / \mathrm{N}]\end{array}$ & $\begin{array}{l}\text { Dry fruits } \\
{[\mathrm{Y} / \mathrm{N}]}\end{array}$ & $\begin{array}{l}\text { Dehiscent } \\
\text { fruits }[\mathrm{Y} / \mathrm{N}]\end{array}$ & $\begin{array}{l}\text { Mean fruit } \\
\text { length }[\mathrm{mm}]\end{array}$ & $\begin{array}{l}\text { Flowering in } \\
\text { rainy } \\
\text { season }[\mathrm{Y} / \mathrm{N}]\end{array}$ \\
\hline Philenoptera laxiflora (Guill. \& Perr.) Roberty & 8 & $\mathrm{~N}$ & $\mathrm{~N}$ & $\mathrm{Y}$ & $\mathrm{Y}$ & Y & 85 & $\mathrm{~N}$ \\
\hline Piliostigma thonningii (Schumach.) Milne-Redh. & 8 & $\mathrm{~N}$ & $\mathrm{~N}$ & $\mathrm{~N}$ & Y & $\mathrm{N}$ & 190 & $\mathrm{~N}$ \\
\hline Prosopis africana (Guill. \& Perr.) Taub. & 15 & $\mathrm{~N}$ & $\mathrm{~N}$ & Y & Y & $\mathrm{N}$ & 115 & $\mathrm{~N}$ \\
\hline Pterocarpus erinaceus Poir. & 12 & $\mathrm{~N}$ & $\mathrm{~N}$ & Y & Y & $\mathrm{N}$ & 55 & $\mathrm{~N}$ \\
\hline Pterocarpus lucens Guill. \& Perr. & 10 & $\mathrm{~N}$ & $\mathrm{~N}$ & Y & Y & $\mathrm{N}$ & 47.5 & $\mathrm{~N}$ \\
\hline Quassia undulata (Guill. \& Perr.) F. Dietr. & 10 & $\mathrm{~N}$ & $\mathrm{~N}$ & Y & $\mathrm{N}$ & $\mathrm{N}$ & 18 & $\mathrm{~N}$ \\
\hline Saba senegalensis (A. DC.) Pichon & 15 & $\mathrm{~N}$ & Y & $\mathrm{N}$ & $\mathrm{N}$ & $\mathrm{N}$ & 85 & $\mathrm{~N}$ \\
\hline Sarcocephalus latifolius (Sm.) E. A. Bruce & 5 & $\mathrm{~N}$ & $\mathrm{~N}$ & $\mathrm{~N}$ & $\mathrm{~N}$ & $\mathrm{~N}$ & 40 & Y \\
\hline Stereospermum kunthianum Cham. & 12 & $\mathrm{~N}$ & $\mathrm{~N}$ & Y & Y & Y & 500 & $\mathrm{~N}$ \\
\hline Strychnos innocua Delile & 12 & $\mathrm{~N}$ & $\mathrm{~N}$ & $\mathrm{~N}$ & $\mathrm{~N}$ & $\mathrm{~N}$ & 42.5 & Y \\
\hline Strychnos spinosa Lam. & 10 & Y & $\mathrm{N}$ & $\mathrm{N}$ & $\mathrm{N}$ & $\mathrm{N}$ & 60 & Y \\
\hline Syzygium guineense (Willd.) DC. & 15 & $\mathrm{~N}$ & $\mathrm{~N}$ & $\mathrm{~N}$ & $\mathrm{~N}$ & $\mathrm{~N}$ & 10 & $\mathrm{~N}$ \\
\hline Tamarindus indica $\mathrm{L}$. & 15 & $\mathrm{~N}$ & $\mathrm{~N}$ & Y & Y & $\mathrm{N}$ & 140 & $\mathrm{~N}$ \\
\hline Terminalia avicennioides Guill. \& Perr. & 8 & $\mathrm{~N}$ & $\mathrm{~N}$ & $\mathrm{~N}$ & Y & $\mathrm{N}$ & 57.5 & $\mathrm{~N}$ \\
\hline Terminalia laxiflora Engl. \& Diels & 12 & $\mathrm{~N}$ & $\mathrm{~N}$ & $\mathrm{~N}$ & Y & $\mathrm{N}$ & 70 & $\mathrm{~N}$ \\
\hline Terminalia macroptera Guill. \& Perr. & 12 & $\mathrm{~N}$ & $\mathrm{~N}$ & $\mathrm{~N}$ & Y & $\mathrm{N}$ & 90 & $\mathrm{~N}$ \\
\hline Terminalia schimperiana Hochst. & 10 & $\mathrm{~N}$ & $\mathrm{~N}$ & $\mathrm{~N}$ & Y & $\mathrm{N}$ & 75 & $\mathrm{~N}$ \\
\hline Trichilia emetica Vahl & 12 & $\mathrm{~N}$ & $\mathrm{~N}$ & Y & Y & Y & 22.5 & $\mathrm{~N}$ \\
\hline Vitellaria paradoxa C. F. Gaertn. & 9 & $\mathrm{~N}$ & Y & $\mathrm{N}$ & $\mathrm{N}$ & $\mathrm{N}$ & 45 & $\mathrm{~N}$ \\
\hline Vitex madiensis Oliv. & 6 & $\mathrm{~N}$ & $\mathrm{~N}$ & Y & $\mathrm{N}$ & $\mathrm{N}$ & 25 & $\mathrm{~N}$ \\
\hline $\begin{array}{l}\text { Xeroderris stuhlmannii (Taub.) Mendonça \& } \\
\text { E. C. Sousa }\end{array}$ & 12 & $\mathrm{~N}$ & $\mathrm{~N}$ & Y & Y & $\mathrm{N}$ & 110 & $\mathrm{~N}$ \\
\hline Ximenia americana $\mathrm{L}$. & 5 & Y & $\mathrm{N}$ & $\mathrm{N}$ & $\mathrm{N}$ & $\mathrm{N}$ & 25 & $\mathrm{~N}$ \\
\hline Zanthoxylum zanthoxyloides (Lam.) Zepern. \& Timle & nler 12 & Y & $\mathrm{N}$ & Y & Y & Y & 5.5 & Y \\
\hline Ziziphus abyssinica A. Rich. & 5 & Y & $\mathrm{N}$ & $\mathrm{N}$ & $\mathrm{N}$ & $\mathrm{N}$ & 17.5 & Y \\
\hline Ziziphus mauritiana Lam. & 5 & Y & $\mathrm{N}$ & $\mathrm{N}$ & $\mathrm{N}$ & $\mathrm{N}$ & 13.5 & $\mathrm{~N}$ \\
\hline Ziziphus mucronata Willd. & 5 & Y & $\mathrm{N}$ & $\mathrm{N}$ & $\mathrm{N}$ & $\mathrm{N}$ & 15 & $\mathrm{~N}$ \\
\hline
\end{tabular}


Our initial set of environmental factors comprised the 19 bioclimatic variables of the Worldclim/Bioclim dataset (HIJMANS \& al., 2005), the SRTM altitude provided with them and a slope layer calculated on the base of this layer with ArcGIS 9.3, as well as vegetation indices (EVI and NDVI) based on MODIS satellite data of the year 2010 from three time slices in the dry season (January), the beginning rainy season (May) and the peak of the vegetation period (September; phenology according to $\mathrm{K}$. McCloy, pers. comm.) obtained from the IRI/LDEO Climate DATA LibRARY (2013) and a layer of tree cover from the Global Landcover Facility (DEFRIES \& al., 2000). All layers were clipped to a rectangle around Burkina Faso $\left(8^{\circ} \mathrm{N}-16^{\circ} \mathrm{N} 6^{\circ} \mathrm{W}-3^{\circ} \mathrm{E}\right)$ to include distribution records from neighbouring countries and thereby reduce edge effects. The MODIS and tree cover layers were resampled to the $1 \mathrm{~km}$ resolution of the Bioclim dataset. Of these 28 layers we excluded some after visual examination because of abrupt changes in the values (e.g. "mean temperature of driest quarter", probably an artefact of calculating these variables on a monthly basis), other layers because we judged them ecologically not important in our study area (e.g. "precipitation of driest month") and after first runs of Maxent also excluded layers that only marginally contributed to model performance throughout the species set. The remaining variables are listed (Table 2).

\section{Modeling approach}

Using the botanical distribution data described above and the environmental factors (see Table 2) as covariates we modeled distributions of 129 woody plant species for our study area with the program Maxent (PHILLIPS \& al., 2006). Maxent is a commonly used program for statistical modeling of species distributions from presence-only records. Its approach is to calculate the probability of occurrence by minimizing the relative entropy between the probability densities of (1) the presence data and (2) the landscape defined in covariate space (for a more detailed explanation, see ELITH \& al., 2011). We randomly assigned $25 \%$ of the points as test data, allowed all feature types (linear, product, quadratic, hinge, threshold and categorical), and calculated five models for each species.

To summarize single species distributions we had to convert the probability values to presence-absence values by applying a threshold. Following the recommendations of LiU \& al. (2005) we used an individual threshold for each species, the "Maximum test sensitivity plus specificity threshold", on the median of the five single models.

In a later step we used VBA routines in Microsoft Access to count presences within each single grid cell (1) for all species and (2) for species groups defined by the functional traits. For quantitative traits we calculated the mean values for the single grid cells. In a further step we used ArcGIS to calculate percentage values by dividing for each grid cell the number of species belonging to a certain group through the number of all species.

\section{Results}

The available plant distribution records are unevenly distributed (Fig. 1A) with highest densities in the areas of the Sahel (between Fadar-Fadar and Gorom-Gorom), the Gourma region (between Fada N'Gourma and Tindangou and between Arly and Diapaga), and around Banfora in the Southwest (see Fig. 1B for all localities mentioned here and below). Densely sampled areas outside Burkina Faso contributing to our models are around Natitingou and Sampeto in northern Benin. Large areas of the central plateau and along the border to Mali on the other hand have a rather low sampling density.

Table 2. - Covariates of the distribution models and their contributions (mean values for all 129 species). Climate and altitude data have been downloaded from the Worldclim website, slope calculated from altitude with ArcGIS, vegetation indices have been downloaded from the IRI/LDEO data library and tree cover from GLCF. Minimal or maximal values showing the importance of a variable are marked in bold.

\begin{tabular}{|c|c|c|c|c|c|c|c|c|}
\hline & Contribution & $\begin{array}{l}\text { Permutation } \\
\text { importance }\end{array}$ & $\begin{array}{l}\text { Training gain } \\
\text { without }\end{array}$ & $\begin{array}{l}\text { Training gain } \\
\text { with only }\end{array}$ & $\begin{array}{l}\text { Test gain } \\
\text { without }\end{array}$ & $\begin{array}{l}\text { Test gain } \\
\text { with only }\end{array}$ & $\begin{array}{c}\text { AUC } \\
\text { without }\end{array}$ & $\begin{array}{c}\text { AUC with } \\
\text { only }\end{array}$ \\
\hline Altitude & 10 & 13.44 & 0.56 & 0.08 & 0.67 & 0.15 & 0.83 & 0.61 \\
\hline Slope & 4.71 & 3.07 & 0.61 & 0.06 & 0.76 & 0.11 & 0.85 & 0.6 \\
\hline Annual mean temperature & 8.79 & 11.74 & 0.61 & 0.19 & 0.76 & 0.31 & 0.85 & 0.71 \\
\hline Maximal temperature of warmest month & 8.41 & 8.15 & 0.62 & 0.26 & 0.79 & 0.43 & 0.85 & 0.75 \\
\hline Mean temperature of warmest quarter & 6.46 & 7.61 & 0.62 & 0.23 & 0.79 & 0.36 & 0.85 & 0.72 \\
\hline EVI Sept & 3.26 & 3.66 & 0.62 & 0.09 & 0.79 & 0.13 & 0.85 & 0.65 \\
\hline NDVI May & 8.7 & 5.66 & 0.63 & 0.23 & 0.8 & 0.35 & 0.85 & 0.72 \\
\hline NDVI Sept & 1.92 & 3.8 & 0.63 & 0.16 & 0.81 & 0.24 & 0.85 & 0.67 \\
\hline Tree cover & 22.79 & 13.93 & 0.61 & 0.24 & 0.89 & 0.21 & 0.85 & 0.73 \\
\hline
\end{tabular}




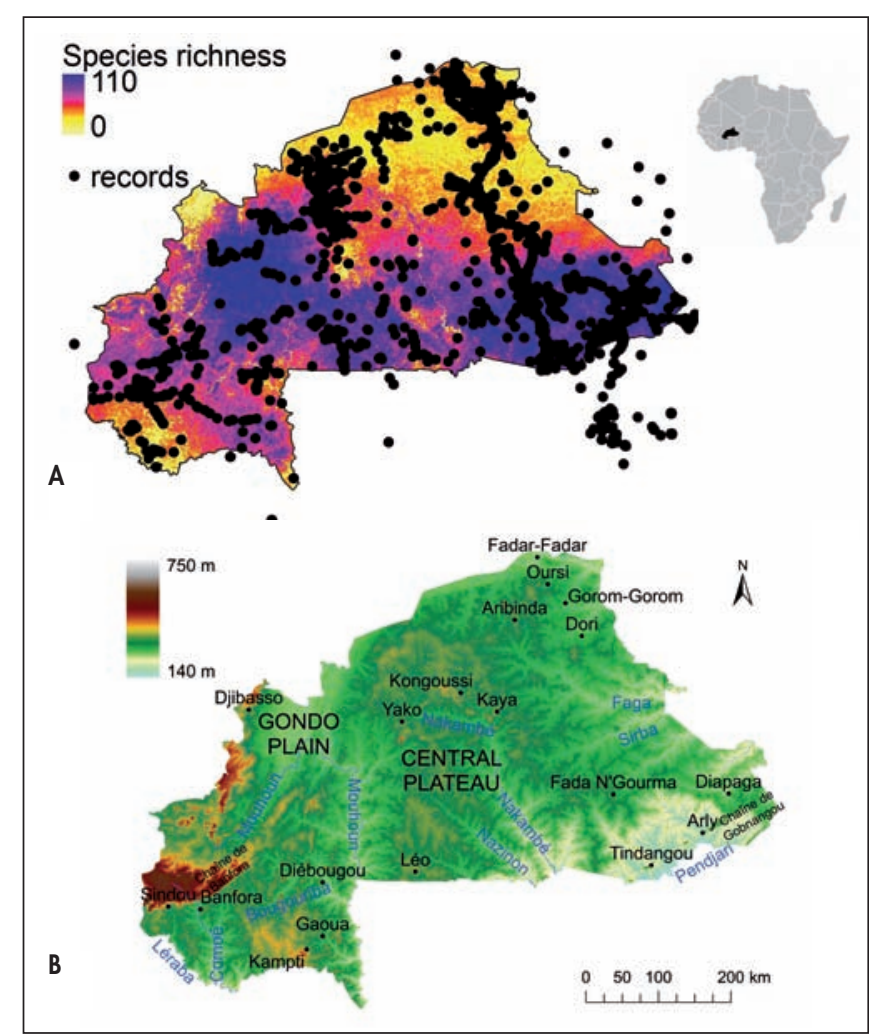

Fig. 1. - Study area. A. Species richness of the 129 woody plants, distribution records and position of Burkina Faso within Africa; B. Names of landscape elements and cities mentioned in the results.

All distribution models had a test AUC above 0.62, the mean value was 0.85 , the values for training AUC were slightly higher (min: 0.69, mean 0.86). Lower AUC values were often encountered in models for species with a preference for azonal habitats including gallery forests and rocks, but also in the baobab (Adansonia digitata L.), a species known to be closely connected with human settlements (DUVALL, 2007).

The species richness of woody plants (represented by the set of 129 species) increased from the Sahelian to the Sudanian Zone with highest values in the Northern Sudanian Zone (Fig. 1A). Apart from the zonal trends, local patterns can also be observed: there are higher values relative to the surroundings in the Falaise de Banfora in the South-West and to a lesser degree also in the Chaîne de Gobnangou in the South-East, the hill chain around Kongoussi and Kaya and the dunes around Oursi. Lower values are found along the valleys of the Nazinon, Mouhoun and Bougouriba.

Plant size (Fig. 2A) shows some clear latitudinal trends. Lowest values $(3 \mathrm{~m})$ are in the Sahel around Aribinda. The northern most part of Burkina's Sahel region near the border with Mali has slightly higher values. Mean plant size is highest
(25 m) in the lowlands of the South-West along the Comoé and Léraba rivers, between the Banfora escarpment and the hills around Kampti.

Spinescence is decreasing from the North to the South (Fig. 2B). Local differences can be seen in a less spinecent species composition in the Chaîne de Gobnangou in the SouthEast and the hills around Kongoussi and Kaya slightly north of the Centre. The Gondo plain in western Burkina Faso has a higher share of spiny species than the sandstone mountains to its West and the central plateau to its East. Within the Sahel the dunes have less spiny species than the peneplain.

Species containing latex (Fig. 2C) are mainly confined to the Sudanian Zone with highest values in sandstone mountains west of the Banfora cliffs with some local 'hotspots' in Mt. Tamiougou near Yako, the hills around Kongoussi and Kaya and the Chaîne de Gobnangou, but also in the hills of Kampti and Gaoua. Fewest species with latex are found in the Subsahel, the slight increase towards the North is due to a lower general species richness and the Sahelian distribution of Calotropis procera (Aiton) W. T. Aiton.

Compound leaves (Fig. 2D) are characteristic for about half of the species throughout the country with only very slight differences. In the area of the Comoé-Léraba reserve in the SouthWest is a lower share of species with compound leaves, higher values are east of Djibasso and at the Sahelian lakes and watercourses of the Subsahel.

Flowering phenology (Fig. 3A) has strong latitudinal trends with most northern species flowering in the rainy season and most southern species in the dry season. Within the South-West, dry season flowering is most prevalent in the lowlands.

Dry fruits (Fig. 3B) as opposed to fleshy fruits are distributed almost equally across the country with slightly higher shares along the Subsahelian rivers Faga and Sirba and the rivers Nakambé, Mouhoun and Bougouriba in the Sudanian Zone. The lowest share of dry fruits is found in the Comoé-Léraba area and the sandstone mountains close to the border of Mali.

Dehiscent fruits (Fig. 3C) are more frequent in plant species of the Sahel and North Sudanian zone with highest values east of Djibasso, in the northeastern Sahel and along the subsahelian rivers Faga and Sirba. Lowest values are found in the sandstone mountains of the West and the areas around Kampti and Léo.

Mean fruit length (Fig. 3D) is generally shorter in the Sahel than in the Sudanian zone with longest fruits in the central plateau, around Djibasso extending northwards, and from Sindou to Diébougou. Shortest fruits are in the area between Aribinda and Dori, but also in the valleys of the Nazinon and the Léraba. 


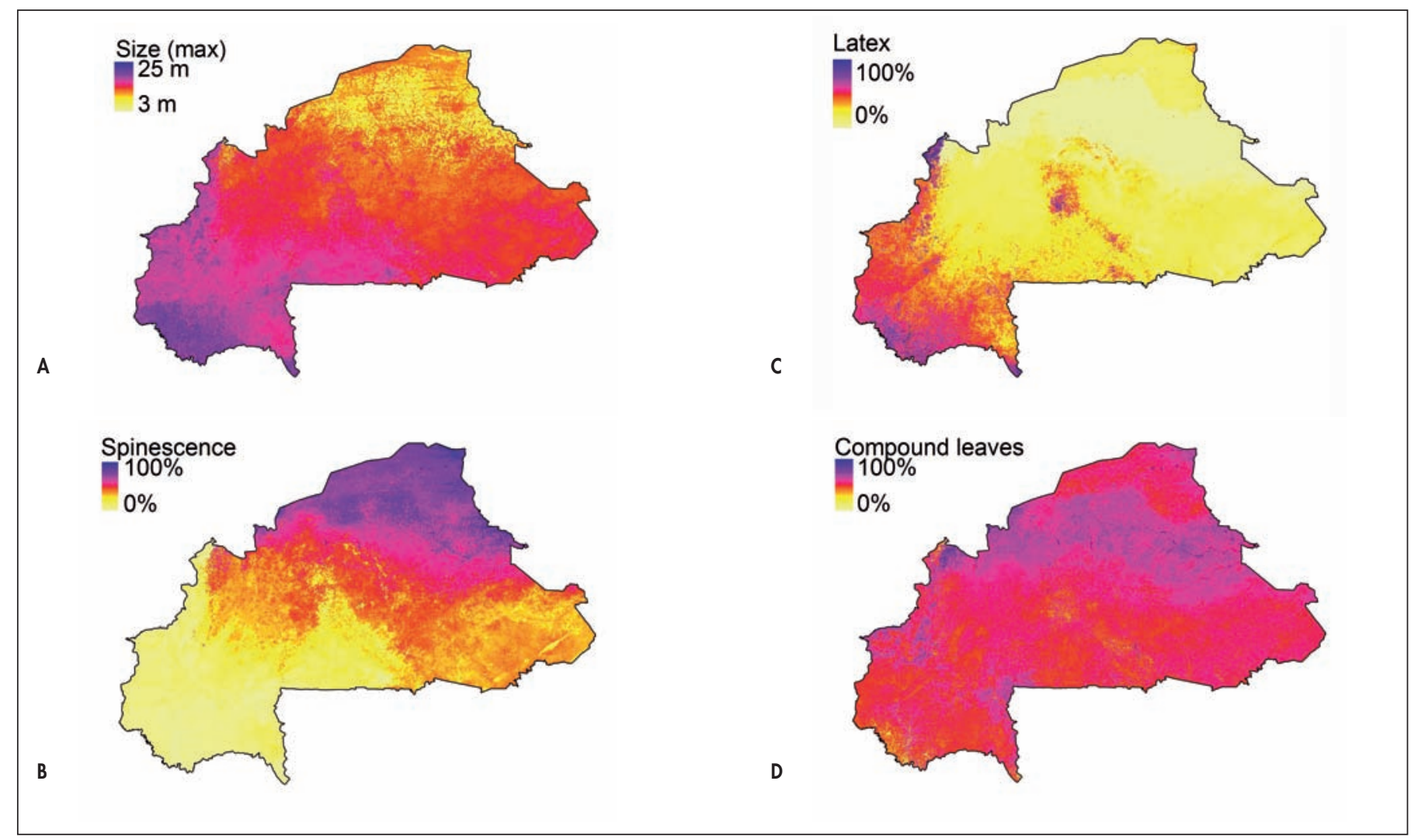

Fig. 2. - Species prediction for a grid cell. A. Average of maximal plant size; B. Percentage of spinescent species; C. Percentage of species containing latex; D. Percentage of species with compound leaves.

\section{Discussion}

Our approach of using stacked species distribution models to analyse biogeographical patterns of woody plants has proven useful, showing both broad scale patterns linked to macroclimate, but also local differences linked with topography. Together with a previous biogeographical study on functional traits of grasses (SCHMIDT \& al., 2011), we now have a detailed idea of the biogeography of the two most important plant groups in the Sudano-Sahelian region of West Africa.

The three most important environmental variables for our models were annual precipitation, tree cover and altitude. The first two go roughly in latitudinal direction, decreasing towards the north. Precipitation parameters have been identified as main drivers of biodiversity in West Africa (WIERINGA \& POORTER, 2004; SCHMIDT \& al., 2005), as water availability is a limiting factor for many species. Tree cover however also shows some local patterns, distinguishing, e.g., protected areas in the Sudanian zone from the parklands. Many specific habitats such as the island forests of the Comoé-Léraba (GNOUMOU \& al., 2011) or the almost treeless bowé (ZWARG, 2008) are characterized by tree cover, but due to the $1 \mathrm{~km}$ resolution of our environmental data, only larger habitat patches may be recognized by the grid data. As opposed to most other variables in our study area, altitude is not linked with latitude and accounts for most of the local patterns shown in our study. Altitude by itself is certainly not of any importance to plants and the differences in Burkina Faso are only subtle. But certain habitat features, usually not easily connected with environmental grid data, are often associated with altitude in our study area. Rocky, rugged terrain with water-conserving fissures, shallow soils and vegetation and thereby also a certain protection from fire are more often found in the 'higher' altitudes.

Several traits showed distinctive geographical patterns, this is especially true for plant size, spinescence and flowering period. For plant size our results are in line with MOLES \& al. (2009) having shown a global latitudinal trend with higher trees in the tropics and a strong dependency on precipitation variables especially in arid and semi-arid regions. Similarly, the patterns in spinescence may be explained with COLEY \& al. (1985) arguing that plants will develop higher levels of defence in environments with low resource availability. 
A

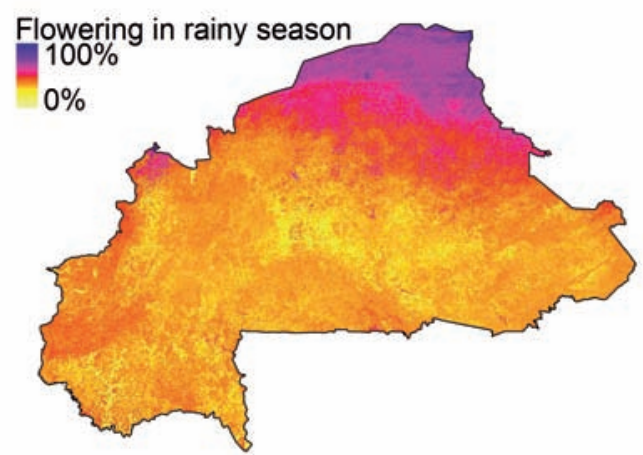

B

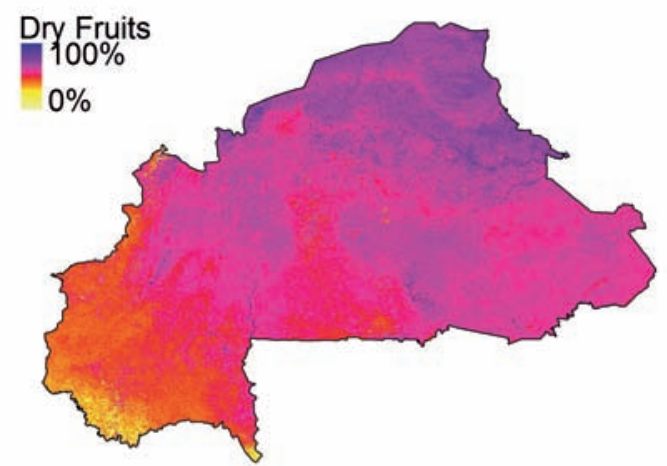

C

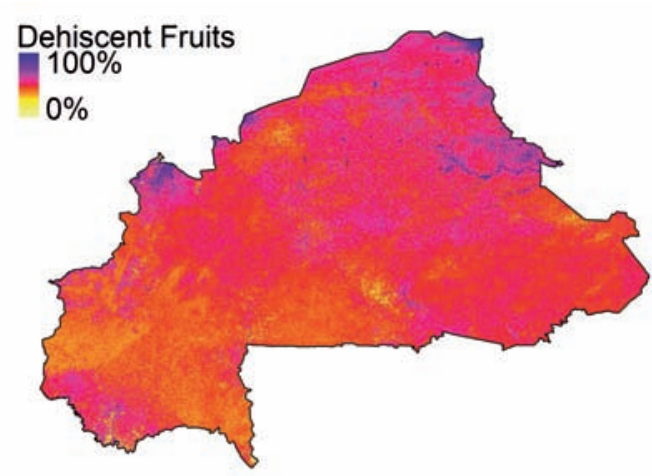

D

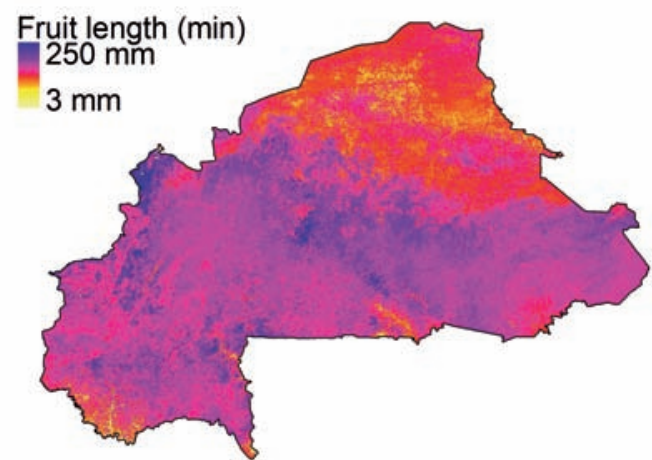

Fig. 3. - Species prediction for a grid cell. A. Percentage of species flowering in rainy season; B. Percentage of species having dry fruits; C. Percentage of species having dehiscent fruits; D. Average of minimal fruit length.

Our observations on rainy season flowering prevalent in the dryer North are in line with the findings of BORCHERT (1983) and Bowers \& DimmitT (1994) who report that the flowering period of tropical trees growing in seasonal climates is influenced by periodical changes in the availability of water and pollinators. In the more humid South water scarcity is less important. Advantages of dry season flowering might be a more efficient pollination less disturbed by foliage and a more effective use of the growing season for fruit development.

Apart from the broad patterns shaped mainly by the precipitation gradient, local differences have been shown between topographical features such as rivers, lowlands and hills. Very interesting is the preference of hills and sandstone mountains amongst the latex-containing woody plants. In our study with a species set limited to the most frequent ones, this included species of Ficus L. and Apocynaceae, but it also holds true for the larger species of Euphorbia L. occurring in the study area.

In the rainforests south of our study area, MAHARJAN \& al. (2011) investigated trait-environment relations of rainforest trees, with strong relations to rainfall, which has been the most important factor in our study as well. Unfortunately there is little overlap between the selected traits of both studies, but their findings of a weak correlation of rainfall parameters with fruit length is in line with Fig. 3D.

\section{Acknowledgements}

Data assessment and compilation in databases has taken place in the frame of the BIOTA project (01 LC 0617 D1) funded by the German Ministry of Education and Research and the SUN project (INCO-031685) funded through the $6^{\text {th }}$ framework programme of the European Commission. Analyses and preparation of the manuscript have taken place in the frame of the UNDESERT project (243906) funded by the $7^{\text {th }}$ framework programme of the European commission and supported by travel funds of the University of Ouagadougou. We thank Dr. Annick Koulibaly and Dr. Dethardt Goetze for contributing data from Ivory Coast and Dr. Fidèle Bognounou and Issaka Ouédraogo for contributing data from Burkina Faso. 


\section{References}

AkoÈGninou, A., W. J. VAn der Burg, L. J. G. VAn Der MAesen, V. Adjakidje, J.-P. Essou, B. Sinsin \& H. Yédomonhan (2006). Flore analytique du Bénin. Backhuys Publishers.

ArbonNIER, M. (2002). Arbres, arbustes et lianes des zones sèches d'Afrique de l'Ouest. 2nd edition. CIRAD, MNHN.

Ataholo, M. (2001). Pflanzensoziologische Untersuchungen der Segetalarten in der Sudanzone Westafrikas. PhD Dissertation. Goethe University, Frankfurt am Main, Germany.

Belem, B., B. M. I. Nacoulma, R. Gbangou, S. Kambou, H. H. Hansen, Q. Gausset, S. Lund, A. Raebild, M. Ouédraogo, D. LOMPo, I. TheILADE \& I. J. Boussim (2007). Use of non wood forest products by local people bordering the "Parc National Kaboré Tambi”, Burkina Faso. J. Transdisc. Environm. Stud. 6: 1-21.

Berhaut, J. (1971-1988). Fl. Ill. Sénégal 1-10. Ministère du Développement rural et de l'hydraulique, Direction des Eaux et Forêts, Dakar.

Böнm, M. (1998). Dorfvegetation in Burkina Faso. Diploma thesis. Goethe University, Frankfurt am Main, Germany.

Borchert, R. (1983). Phenology and control of flowering in tropical trees. Biotropica 15: 81-89.

Bowers, J. E. \& M. A. DimmitT (1994). Flowering phenology of six woody plants in the Northern Sonoran Desert. Bull. Torrey Bot. Club 121: 215-229.

Brunken, U., M. Schmidt, S. Dressler, T. JANSSEn, A. Thiombiano \& G. ZIZKA (2008). www.westafricanplants.senckenberg.de An image-based identification tool for West African Plants. Taxon 57: 1027-1028.

Coley, P. D., J. P. BRyant \& F. S. Chapin (1985). Resource Availability and Plant Antiherbivore Defense. Science 230: 895-899.

Defries, R. S., M. C. Hansen, J. R. G. Townshend, A. C. Janetos \& T. R. Loveland (2000). A new global 1-km dataset of percentage tree cover derived from remote sensing. Global Change Biol. 6: 247-254.

DENSCHLAG, J. (1998). Ethnobotanische und pflanzensoziologische Untersuchungen der Gehölzvegetation bei den FulBe im Südosten von Burkina Faso (Westafrika). Diploma thesis. Goethe University, Frankfurt am Main, Germany.

Duvall, C. S. (2007). Human settlement and baobab distribution in south-western Mali. J. Biogeogr. 34: 1947-1961.

Elith, J., S. J. Phillips, T. Hastie, M. Dudik, Y. E. CheE \& C. J. YATES (2011). A statistical explanation of MaxEnt for ecologists. Diversity \& Distrib. 17: 43-57.

Gnoumou, A., F. Bognounou, K. Hahn \& A. Thiombiano (2011). Woody plant diversity and stand structure in the ComoéLéraba reserve, southwestern Burkina Faso (West Africa). J. Biol. Sci. 11: 111-123.

Hahn, K. (1996). Die Pflanzengesellschaften der Savannen im Südosten Burkina Fasos (Westafrika). Ihre Beeinflussung durch den Menschen und die naturräumlichen Gegebenheiten. $\mathrm{PhD}$ Dissertation. Goethe University, Frankfurt am Main, Germany.
Hahn, K., R. Wittig, M. Schmidt, G. Zizka, A. Thiombiano \& B. Sinsin (2010). La végétation de l'Afrique de l'Ouest. In: Thiombiano, A. \& D. Kampmann (ed.), Atlas de la biodiversité de l'Afrique de l'Ouest, Tome II: Burkina Faso: 6774. BIOTA, Ouagadougou \& Frankfurt am Main.

Hennenberg, K. J., D. Goetze, L. Kouame, B. Orthmann \& S. POREMBSKI (2005). Border and ecotone detection by vegetation composition along forest-savanna transects in Ivory Coast. J. Veg. Sci. 16: 301-310.

Hijmans, R. J., S. E. Cameron, J. L. Parra, P. G. Jones \& A. JARVIS (2005). Very high resolution interpolated climate surfaces for global land areas. Int. J. Climatol. 25: 1965-1978.

Hutchinson, J., J. M. Dalziel, R. W. J. KeAy \& F. N. Hepper (1954-1972). Fl. W. Trop. Africa 1-3. $2^{\text {nd }}$ Ed. The Whitefriars Press.

IRI/LDEO CLIMATE DATA LIBRARY (2013). [www.iridl.ldeo.columbia.edu].

Janssen, T., M. Schmidt, S. Dressler, K. Hahn, M. Hien, S. Konate, A. M. Lykke, A. Mahamane, B. Sambou, B. Sinsin, A. Thiombiano, R. Wittig \& G. ZizkA (2011). Addressing data property rights concerns and providing incentives for collaborative data pooling: the West African Vegetation Database approach. J. Veg. Sci. 22: 614-620.

KÉRÉ, U. (1996). Die Dorf- und Savannenvegetation in der Region Tenkodogo (Burkina Faso). PhD Dissertation. Goethe University, Frankfurt am Main, Germany.

KIRCHMAIR, I. (2009). Flora und Vegetation auf Termitenhügeln in Nordbenin. Diploma thesis. Goethe University, Frankfurt am Main, Germany.

Klopper, R. R., L. Gautier, C. Chatelain, G. F. Smith \& R. SPICHIGER (2007). Floristics of the angiosperm flora of subSaharan Africa: an analysis of the African Plant Checklist and Database. Taxon 56: 201-208.

Koulibaly, A., D. Goetze, D. Traore \& S. Porembski (2006). Protected versus exploited savannas: characteristics of the Sudanian vegetation in Ivory Coast. Candollea 61: 425-452.

KROHMER, J. (2004). Umweltwahrnehmung und-klassifikation bei Fulbegruppen in verschiedenen Naturräumen Burkina Fasos und Benins. PhD Dissertation. Goethe University, Frankfurt am Main, Germany.

KüPPERS, K. (1996). Die Vegetation der Chaîne de Gobnangou. PhD Dissertation. Goethe University, Frankfurt am Main, Germany.

Liu, C. R., P. M. Berry, T. P. Dawson \& R. G. Pearson (2005). Selecting thresholds of occurrence in the prediction of species distributions. Ecography 28: 385-393.

Louppe, D., A. A. Oteng-Amoako \& M. Brink (2008). Plant resources of tropical Africa 7(1) - Timbers 1. PROTA foundation, Backhuys.

LyKKe, A. M., M. K. Kristensen \& S. GAnABA (2004). Valuation of local use and dynamics of 56 woody species in the Sahel. Biodivers. \& Conservation 13: 1961-1990. 
Maharjan, S. K., L. Poorter, M. Holmgren, F. Bongers, J. J. WIERINGA \& W. D. HAWTHORNE (2011). Plant functional traits and the distribution of West African rain forest trees along the rainfall gradient. Biotropica 43: 552-561.

Mbayngone, E. (2008). Flore et végétation de la réserve partielle de faune de Pama, sud-est du Burkina Faso. PhD Dissertation. University of Ouagadougou, Burkina Faso.

Moles, A. T., D. I. Warton, L. Warman, N. G. Swenson, S. W. Laffan, A. E. Zanne, A. Pitman, F. A. Hemmings \& M. R. LEISHMAN (2009). Global patterns in plant height. J. Ecol. 97 : 923-932.

OuÉDraogo, A. (2006). Diversité et dynamique de la végétation ligneuse de la partie orientale du Burkina Faso. PhD Dissertation. University of Ouagadougou, Burkina Faso.

OuÉdraogo, O. (2009). Phytosociologie, dynamique et productivité de la végétation du Parc national d'Arly (Sud-Est du Burkina Faso). PhD Dissertation. University of Ouagadougou, Burkina Faso.

OuobA, P., A. M. LyKke, I. J. Boussim \& S. Guinko (2006). Medical plants of the classified forest of Niangoloko. Etudes Fl. Vég. Burkina Faso 10: 5-16.

Phillips, S., R. Anderson \& R. Schapire (2006). Maximum entropy modeling of species geographic distributions. Ecol. Modelling 190: 231-259.

Sambaré, O., F. Bognounou, R. Wittig \& A. Thiombiano (2011). Woody species composition, diversity and structure of riparian forests of four watercourses types in Burkina Faso. J. Forest. Res. 22: 145-158.

Schmidt, M. (2006). Pflanzenvielfalt in Burkina Faso - Analyse, Modellierung und Dokumentation. PhD Dissertation. Goethe University, Frankfurt am Main, Germany.

Schmidt, M., T. Janssen, S. Dressler, K. Hahn, M. Hien, S. Konate, A. M. Lykke, A. Mahamane, B. Sambou, B. Sinsin, A. ThiomBiAnO, R. WitTig \& G. ZizKa (2012). The West African Vegetation Database. Biodivers. \& Ecol. 4: 105-110.

Schmidt, M., H. Kreft, A. Thiombiano \& G. ZizKa (2005). Herbarium collections and field data-based plant diversity maps for Burkina Faso. Diversity \& Distrib. 11: 509-516.

Schmidt, M., A. Thiombiano, A. ZizKa, K. König, U. Brunken \& G. ZiZKA (2011). Patterns of plant functional traits in the biogeography of West African grasses (Poaceae). African J. Ecol. 49: 490-500.
Sieglstetter, R. (2002). Wie die Haare der Erde - Vegetationsökologische und soziokulturelle Untersuchungen zur Savannenvegetation der Südsudanzone Westafrikas und ihrer Nutzung und Wahrnehmung durch die ländliche Bevölkerung am Beispiel der Region Atakora im Nordwesten Benins. PhD Dissertation. Goethe University, Frankfurt am Main, Germany.

TAÏTA, P. (2003). Use of woody plants by locals in Mare aux Hippopotames Biosphere Reserve in western Burkina Faso. Biodivers. \& Conservation 12: 1205-1217.

Thiombiano, A. (2005). The Combretaceae in Burkina Faso: Taxonomy, ecology, dynamic and regeneration of species. $\mathrm{PhD}$ Dissertation. University of Ouagadougou, Burkina Faso.

Thiombiano, A., M. Schmidt, S. Da, K. Hahn, G. Zizka \& R. Wittig (2010). Les plantes à fleurs. In: Thiombiano, A. \& D. KAMPMANN (ed.), Atlas de la biodiversité de l'Afrique de l'Ouest, Tome II: Burkina Faso: 182-190. BIOTA, Ouagadougou \& Frankfurt am Main.

Thiombiano, A., M. Schmidt, S. Dressler, A. Ouédraogo, K. HAHN \& G. ZIZKA (2012). Catalogue des plantes vasculaires du Burkina Faso. Boissiera 65.

Thiombiano, A., M. Schmidt, H. Kreft \& S. Guinko (2006). Influence of the climatic gradient on the distribution of Combretaceae species in Burkina Faso (West Africa). Candollea 61: 189-213.

West African Vegetation (2013). [westafricanvegetation.senckenberg.de].

Wieringa, J. J. \& L. Poorter. (2004). Biodiversity hotspots in West Africa; patterns and causes. In: POORTER, L. F. BONGERS, F. Kounme \& W. D. Hawthorne (ed.), Biodiversity of West African forests. An ecological atlas of woody plant species: 61-72. CABI Publishing.

Wittig, R., M. Schmidt \& A. Thiombiano (2004). Distribution maps of the species of the genus Acacia L. in Burkina Faso. Etudes Fl. Vég. Burkina Faso 8: 19-26.

ZwARG, A. (2008). Flora und Vegetation auf Lateritkrusten im Südosten Burkina Faso. Diploma thesis. Goethe University Frankfurt am Main, Germany. 